\title{
Global advertising market of eco-friendly products in developing countries: A review of the current trends and prospects
}

\author{
O.P. Yevsuykov¹, O.O. Akhmedova², S.I. Sysoieva3, S. V. Stankevych ${ }^{3}$, \\ A.A. Vasiliev", Ye.S. Anichkin ${ }^{4}$ \\ ${ }^{1}$ Institute of Public Administration and Research in Civil Protection, 18, Rybalska St, Pechersk district, Kyyiv, \\ 01011, Ukraine \\ 2S. Kuznets Kharkiv National University of Economics, 9A Nauky Avenu, Kharkiv, 61166, Ukraine \\ 3 V.V. Dokuchaev Kharkiv National Agrarian University, v. Dokuchaevske, Kharkiv region, 62483, Ukraine \\ ${ }^{4}$ Altai State University, Barnaul, Russian Federation
}

Corresponding author E-mail: sergejstankevich1986@gmail.com

Received: 11.09.2020. Accepted: 22.10.2020

\begin{abstract}
The analysis of the current trends and future prospects of extension of advertising market of eco-friendly products in developing countries at the world level is carried out in the article. In particular, the assessment of the current structure of world advertising market of eco-friendly products is made. The determination of retrospective tendencies of development of advertising market of eco-friendly products in developing countries on the example of Ukraine is carried out. The identification of prospective volumes of advertising market of eco-friendly products in developing countries is given. The complex of actions allowing stimulating advertising activity concerning eco-friendly products in developing countries with the prospect of increase of their share within the world advertising market of eco-friendly products is offered.
\end{abstract}

Keywords: Eco-friendly products; Advertising market; Tendencies; Perspectives; Ukraine

\section{Introduction}

Advertising activity expands and improves sales channels, accelerates money turnover, increasing overall effectiveness of national economy functioning and promoting its integration into world economy. At the same time, considering dynamic development of the advertising market, systematic improvement of advertising technologies, in particular, innovative types and forms of advertisement distribution, some problems are observed within existence of the modern advertising market. Many foreign scientists offered effective approaches to solution of various problems, which arise in the process of functioning of the advertising market in present conditions. In particular, different authors pay essential attention to essence of advertising, its types and means of its distribution and the features of implementation of advertising activity (Bovee, Arens, 1989; Bovee, Thill, 1992; Nelson, 1974).

However, the questions of determination of future volumes of the world advertising market and the researches of prospects of developing countries on the example of Ukraine within global advertising market are still insufficiently studied. Thus especially relevant is studying of tendencies of development of the world advertising market in modern conditions. Proceeding from relevance of the chosen research subject, the aim of our review was to determine the current trends and future prospects of advertising market in developing countries.

\section{Methodology}

We planned to perform the analysis of the current structure of the world advertising market; to assess the retrospective development tendencies in the advertising and communication market of developing countries and in Ukraine; to identify the perspectives of the advertising market in developing countries and Ukraine; to elaborate the stimulation measurements for extension of advertising market for eco-friendly products in developing countries.

\section{Results and Discussion}

Now-a-days $41.6 \%$ of the world advertising market of eco-friendly products is occupied by the USA, Japan makes $10 \%$, and the combined share of Great Britain, Germany and France is about 16\% (Figure 1). At the same time, the national markets of the leading countries on advertising volumes grow very slowly. 

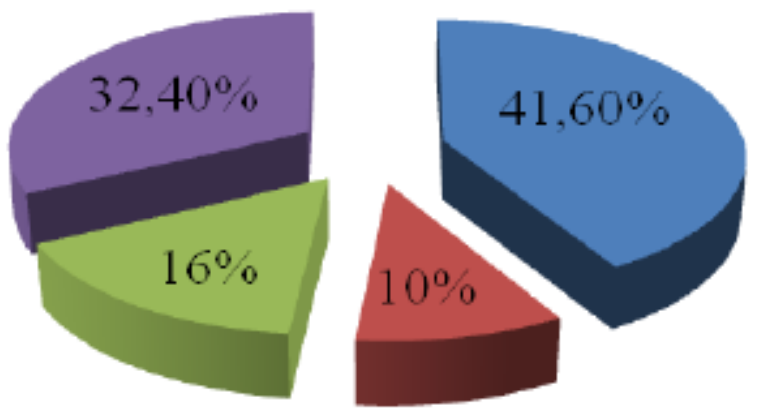

USA

Japan

Great Britain, Germany, France

Other countries

Figure 1. Structure of the world advertising market of eco-friendly products in 2018 (own compilation).

The total volume of the world advertising market of eco-friendly products in 2014 was near 503 billion USD. Thus, it is possible to see from Table 1 that the $1^{\text {st }}$ place in the world advertising market in 2014 was taken by the USA with the volume of advertising expenses near 166.9 billion USD or $33.2 \%$ of the total amount of the global advertising market of eco-friendly products. As for Japan, its advertising market share was about 10.4\% in 2014 (the advertising expenses volume was near 52.4 billion USD).

Table 1. World structure of advertising market for eco-friendly products in 2014 and 2017.

\begin{tabular}{ccc} 
Country & $\begin{array}{c}\text { Advertising expenses, billion USD } \\
(\mathbf{2 0 1 4 )}\end{array}$ & $\begin{array}{c}\text { Advertising expenses, billion } \\
\text { USD (2017) }\end{array}$ \\
USA & 166.9 & 190.27 \\
Japan & 52.4 & 56.25 \\
China & 40.95 & 55.36 \\
Germany & 23.18 & 24.15 \\
Great Britain & 20.35 & 23.96 \\
Brazil & 15.86 & 18.88 \\
Australia & 13.07 & 14.26 \\
France & 12.15 & 11.30 \\
Canada & 11.59 & 10.83 \\
South Korea & 10.61 & 13.76 \\
Indonesia & 11.88 & 13.34 \\
\hline
\end{tabular}

Source: Own compilation.

China took the $3^{\text {rd }}$ place of the world advertising market of eco-friendly products with the volume of advertising expenses near 40.95 billion USD or advertising market share of $8.1 \%$. Shares of the advertising market of Germany and Great Britain reached $4.6 \%$ and $4.0 \%$ accordingly. As for the shares of advertising market of Brazil, Australia, France, Canada and South Korea - they also differ insignificantly and reached $3.2 \%, 2.6 \%, 2.4 \%, 2.3 \%$ and $2.1 \%$ accordingly in 2014 . The total volume of the world advertising market of eco-friendly products in 2017 was near 505 billion USD. The $1^{\text {st }}$ place in the world advertising market of ecofriendly products in 2017 was taken by the USA with the volume of advertising expenses near 190.27 billion USD or $37.7 \%$ of the total world amount. Thus, the volume of the USA advertising market of eco-friendly products increased in 2017 by 23.37 billion USD in comparison with 2014.

As for Japan, its eco-friendly products advertising market share was about $11.1 \%$ in 2017 (the advertising expenses volume was near 56.25 billion USD). So, the volume of eco-friendly products advertising market of Japan increased by 3.85 billion USD in 2017 in comparison with 2014. China again took the $3^{\text {rd }}$ place of the world advertising market of eco-friendly products with the volume of advertising expenses near 55.36 billion USD or advertising market share of $11.0 \%$. Therefore, the volume of advertising market of eco-friendly products of China increased by 14.41 billion USD in 2017 in comparison with 2014.

Shares of the advertising market of eco-friendly products of Germany and Great Britain reached $4.8 \%$ and $4.7 \%$ accordingly. As for the shares of advertising market of eco-friendly products of Australia, South Korea, Russia and Indonesia - they also differ insignificantly and reached $2.8 \%, 2.7 \%, 2.6 \%$ and $2.6 \%$ accordingly in 2017 . Thus, actually distribution of the world advertising market of eco-friendly products in 2017 looked identically 2014 with only the only difference that Russia and Indonesia got to the top ten countries of the global advertising market of eco-friendly products instead of France and Canada in 2017. Thus, as it is possible to see from the carried-out analysis, the USA and Japan remain leaders of the world advertising market of eco-friendly products already at least within the last 4 years.

As for the further forecast of development of the world advertising market of eco-friendly products, it is possible to sign that the largest markets (the USA, China, Japan, Great Britain and Germany) will make $57 \%$ of the advertising market of eco-friendly products between 2018 and 2020. At the same time, it is expected that the volume of the world advertising market of eco-friendly 
products will be 544 billion USD in 2019. Distribution of the world advertising market of eco-friendly products by advertising means is expected in the following format in 2019 (Figure 2).

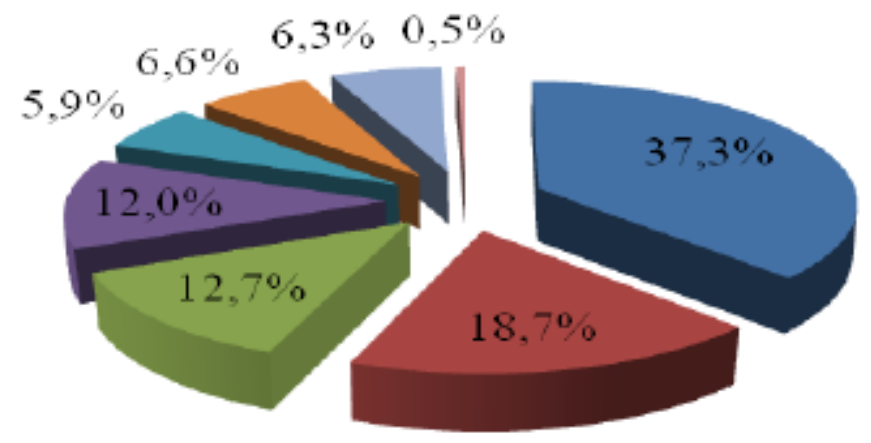

- TV
- Desktop Internet
- Mobile Intenet
- Newspapers
- Magazines
- Online Video
- Radio
- Cinemas

Figure 2. Expected distribution of the world advertising market of eco-friendly products by advertising means in 2019. Source: own compilation by the world advertising market was stabilized (2014); http://www.advertology.ru/article117805.htm/.

Thus, it is expected that the greatest share of the world advertising market of eco-friendly products will belong to TV advertising (37.3\%) in 2019. The desktop Internet will take the second place $-18.7 \%$. The shares of the advertising market of eco-friendly products relating to the Mobile Internet and newspapers will be practically identical and will approximately make $12.7 \%$ and $12.0 \%$ accordingly. The shares of magazines, online video and radio will make $5.9 \%, 6.6 \%$ and $6.3 \%$ accordingly. The smallest share of the advertising market of eco-friendly products will be taken by movie theaters $-0.5 \%$. However, it should be noted that Ukraine, for example, is not the leading country concerning advertising development in the world.

In general, the dynamics of change of total amount of the advertising and communication market of developing countries on the example of Ukraine during 2007-2016 is shown in Figure 3. It is possible to see from Figure 3 that dynamics of change of the advertising and communication market of eco-friendly products of developing countries on the example of Ukraine displays rapid growth throughout the beginning of the specified period, except 2009 which was the following after crisis 2008 when the total amount of the advertising and communication market of developing countries on the example of Ukraine showed the rate of falling at the level of $24 \%$.

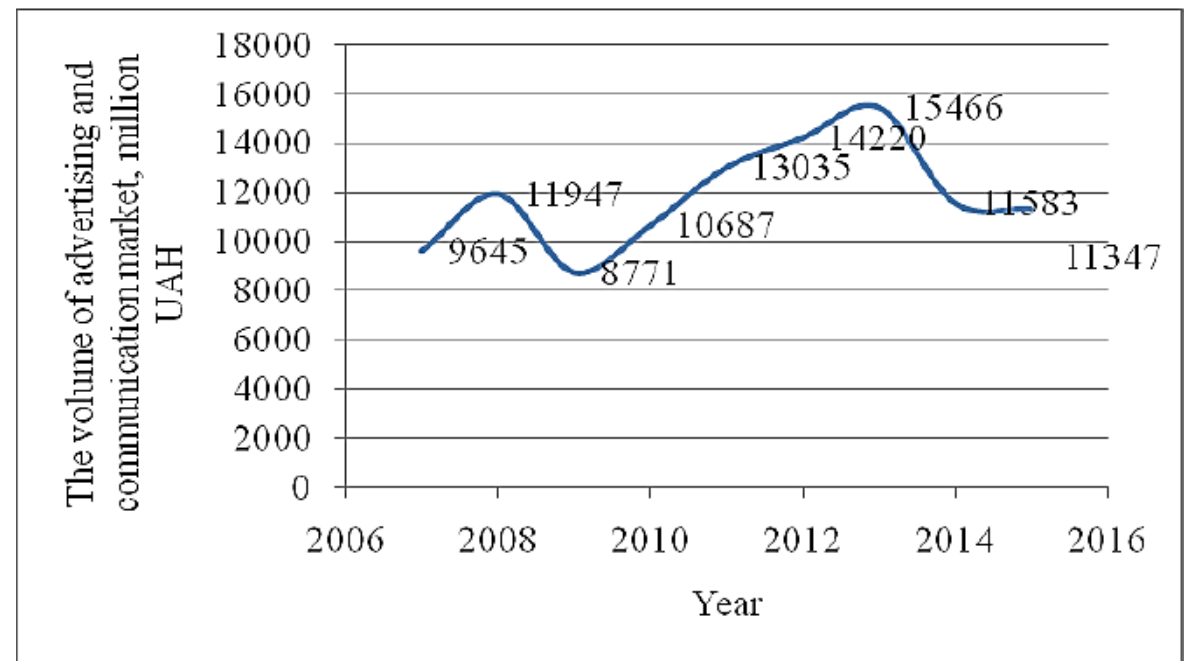

Figure 3. Dynamics of change of volume of advertising and communication market of eco-friendly products in developing countries on the example of Ukraine during 2007-2016. Source: own compilation.

The following 2011-2014 were designated by fluctuation of volumes of the advertising and communication market in developing countries on the example of Ukraine. Concerning 2015-2016, volumes of the domestic advertising and communication market of Ukraine decreased against background of the crisis in the country. Therefore, in 2016 the volume of the advertising and communication market in developing countries on the example of Ukraine decreased in comparison with 2014 by 3883 million UAH or for $25 \%$. Concerning its change in comparison with the previous 2015 , its volume decreased by 236 million UAH or for $2 \%$. If to compare the value of volumes of the advertising market of eco-friendly products in developing countries on the example of Ukraine in 2016 and in 2008 in general, it is expedient to note that 2016 shows the value, which is even lower, than value of 2008 for 600 million UAH, or for $5 \%$. Such situation can be caused by increase in number of violations of the advertising legislation against the background of lack of constant system of state regulation of advertising activity in developing countries. Thus, because of the conducted researches it is possible to make a conclusion that transformation of advertising of developing countries on the example 
of Ukraine into qualitatively new form of production relations reflects a positive tendency of further improvement of mechanisms of state regulation in the sphere of advertising activity in developing countries. However, advertising of Ukraine is not developed at the present stage so that Ukraine could be included into world top ten countries of the advertising industry. That is why forecasting of perspective tendencies of development of the Ukrainian advertising market of eco-friendly products for the purpose of identification of the specified opportunities is expedient. It is possible to obtain statistical data for forecasting of further tendencies of development of the advertising market of eco-friendly products in developing countries on the example of Ukraine taking away the sum of the agency commissions and the fees and also not media part from the total amount of the advertising and communication market of developing countries on the example of Ukraine during 2012-2018 (Figure 4).

It is offered to realize the forecasting of perspective volume of advertising market of eco-friendly products in developing countries on the example of Ukraine by means of regression analysis. Figure 4 shows the diagram of dependence of volumes of advertising market of eco-friendly products in developing countries on the example of Ukraine on the given intervals of time (years) for determination of expedient regression function which needs to be used for implementation of forecasting of perspective volumes of advertising market of eco-friendly products in developing countries on the example of Ukraine during the next three years. The Figure 4 allows seeing nonlinear dependence between volumes of advertising market of eco-friendly products in developing countries on the example of Ukraine and the time interval.

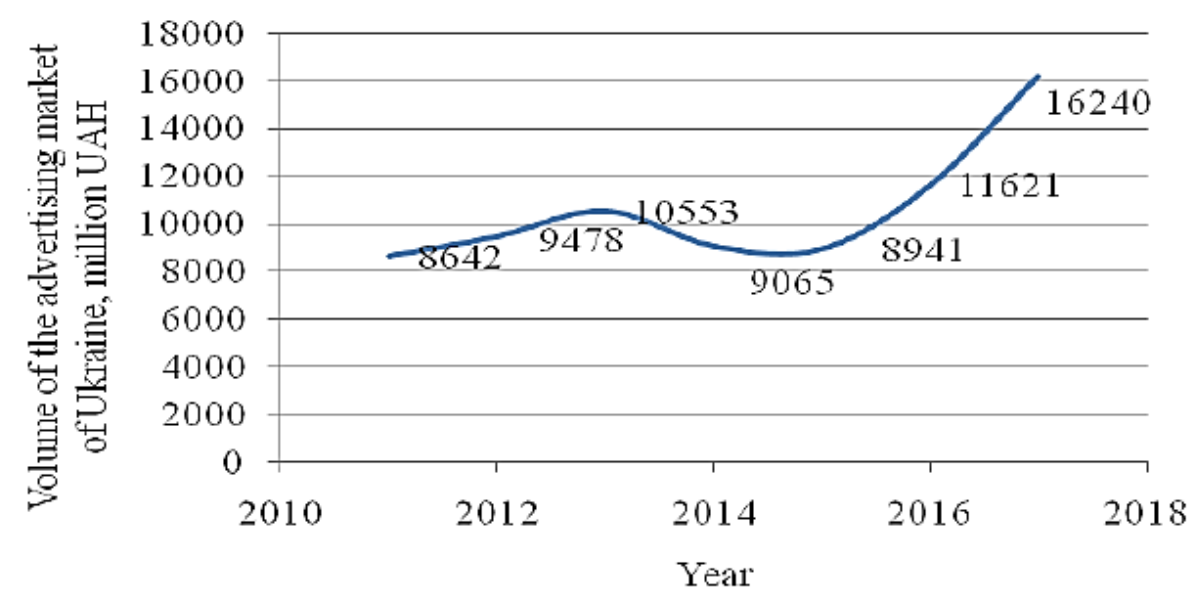

Figure 4. The tendencies of change of volume of the advertising market of eco-friendly products in developing countries on the example of Ukraine during 2012-2018. Source: own compilation.

Thus, Figure 4 illustrates the non-linear change of volume of advertising market of eco-friendly products in developing countries on the example of Ukraine during 2012-2018. The regression analysis is the theoretical basis of creation of the forecast of perspective volume of advertising market of eco-friendly products. The given analysis is based on retrospective dynamics of change of volume of advertising market of eco-friendly products in developing countries on the example of Ukraine and assumes determination of its perspective values based on regression function (Wilson, Keating, 1994). The parameters of one-factorial linear regression function, which is the basis for forecasting of perspective volumes of advertising market of eco-friendly products, are calculated with the help of the smallest squares method.

The one-factorial linear regression function for forecasting of the perspective volumes of advertising market of eco-friendly products is the following:

$$
Y=3649.5 x-735124.67
$$

Where $x$-Time interval (year); $y$-Volume of advertising market of eco-friendly products in developing countries on the example of Ukraine million UAH.

The multiple coefficient of determination is the Criterion of adequacy and reliability of the obtained model. The prognosis of advertising market for eco-friendly products in Ukraine is presented below (Table 2).

Table 2. The expected dynamics in advertising market of eco-friendly products in Ukraine during 2019-2020

\begin{tabular}{cc}
\hline Year & $\begin{array}{c}\text { Expected volume of the advertising market of } \\
\text { eco-friendly products in Ukraine, million UAH }\end{array}$ \\
2019 & 17518 \\
2019 & 19939 \\
2020 & 22359 \\
\hline
\end{tabular}

Source: Own compilation.

At the same time, taking into account the forecasts of experts of the International Monetary Fund concerning growth rates of the Ukrainian economy in 2019 it should be noted that it is expected approximately at the level of 3.2\% (Table 3).

Compared the expected values of advertising market in Ukraine for the next three years it is was possible to register that these values significantly differ (Table 4). So concerning forecasts of the All-Ukrainian advertising coalition, the volume of the advertising market of eco-friendly products in Ukraine will reach 20460 million UAH in 2019. Concerning the results of forecasting by means of the regression function, its value will approximately be 17518 million UAH in 2019, i.e., considering the existing tendencies, the volume of advertising of eco-friendly products market in Ukraine will increase, but the growth rate will be much lower. As it is possible to see from Table 5, the expected growth rate of volume of advertising market of eco-friendly products in developing 
countries on the example of Ukraine according to results of the forecast received by use of the regression function is nearly 3 times less than its expected growth rate received according to assessment of experts of the All-Ukrainian advertising coalition in 2019.

Table 3. The comparative characteristic of forecasts of volume of the advertising market of eco-friendly products in developing countries on the example of Ukraine for 2018-2019.

Indicator

The results
of 2018,
million UAH

The forecast for 2019, million UAH (All-Ukrainian advertising coalition)

$\begin{array}{cc}\text { The forecast for } \\ \text { Growth } & \begin{array}{c}\text { 2019, million } \\ \text { rate, \% } \%\end{array} \\ \begin{array}{c}\text { (regression } \\ \text { function ) }\end{array}\end{array}$

Growth rate, \%

The advertising market of eco-friendly products in

16240

20460

26

17518

7.9

Source: Own compilation.

Accordingly, the growth rate of advertising market of eco-friendly products in Ukraine at the level of $26 \%$ in 2019 cannot be considered as a real value, considering that the volume of advertising market of eco-friendly products in Ukraine decreased during 2014-2016 (in particular it decreased for 14\% in 2015 in comparison with the previous 2014 and also decreased for $1.4 \%$ in 2016 in comparison with the previous 2015).

Table 4. The dynamics of change of volume of advertising market of eco-friendly products in developing countries on the example of Ukraine during 2012-2020, million UAH.

\begin{tabular}{ccc}
\hline Year & $\begin{array}{c}\text { Volume of advertising market of eco-friendly products in } \\
\text { Ukraine, million UAH }\end{array}$ & Growth rate, \% \\
2012 & 8642 & - \\
2013 & 9478 & 9.7 \\
2014 & 10553 & 11.3 \\
2015 & 9065 & -14.1 \\
2016 & 8941 & -1.4 \\
2017 & 11621 & 30.0 \\
2018 & 16240 & 39.7 \\
2019 & 19566 & 20.5 \\
2019 & 23216 & 18.7 \\
2020 (prospective & & 15.7 \\
value) & 26865 & \\
\hline
\end{tabular}

Source: Own compilation.

Thus, the general dynamics of change of volume of advertising market of eco-friendly products in developing countries on the example of Ukraine for 2012-2020 is shown in Table 4. As it is possible to see from Table 4, the steady increase in volume of advertising market of eco-friendly products in developing countries on the example of Ukraine will be observed during 2019-2020. At the same time, its growth rate will be gradually slowed down eventually.

If to carry out recalculation of perspective volumes of advertising market of eco-friendly products in developing countries on the example of Ukraine in USD, it is possible to receive their following dynamics for the next three years (Table 5). If to take into account that according to the experts' assessments the world advertising market of eco-friendly products will make 559 billion USD in 2019 , it is possible to calculate the corresponding share of advertising market of eco-friendly products in developing countries on the example of Ukraine.

Table 5. The perspective dynamics of change of volume of advertising market of eco-friendly products in developing countries on the example of Ukraine during 2018-2020, billion USD

\begin{tabular}{cc}
\hline Year & $\begin{array}{c}\text { Volume of advertising market of eco-friendly products in Ukraine, } \\
\text { billion USD }\end{array}$ \\
2018 & 0.72 \\
2019 & 0.86 \\
2020 & 0.99 \\
\hline
\end{tabular}

Source: Own compilation.

Thus, the share of advertising market of eco-friendly products in Ukraine at the world level will make $0.2 \%$ in 2019 that is a very negative indicator. One of the possible reasons of the given situation is the imperfection of the organizational and legal mechanism of state regulation of advertising activity in developing countries on the example of Ukraine.

So, in the context of the economic direction of improvement of state policy in the sphere of advertising activity in developing countries on the example of Ukraine it is supposed:

- Reduction of tax burden of the organizations that are engaged in development and distribution of advertising.

- Organization of competitions and stimulation by means of grants of the most successful innovative advertising projects. 
- Full support of research and design works and stimulation of demand for innovative projects that, in turn, will have a positive impact on processes of development of both innovative and classical advertising.

The one-factorial function of linear regression is a basis for creation of model of forecasting of perspective volumes of advertising market of eco-friendly products in developing countries on the example of Ukraine. The multiple coefficient of determination, which is the criterion of adequacy of the received model, is the closest to one that confirms the high degree of reliability of expected values. Nevertheless, the model partially considers influence of different factors on development of advertising market of ecofriendly products in developing countries on the example of Ukraine. Therefore, it is necessary to consider the greatest possible quantity of these factors in perspective researches.

\section{Conclusion}

The greatest shares of advertising market of eco-friendly products in 2017-2018 belonged to the USA, Japan and China. Assessment of retrospective tendencies of development of the advertising and communication market in developing countries showed that the volume of the advertising and communication market in developing countries on the example of Ukraine changed not linearly during 2007-2016. It demonstrated the existence of certain problems concerning the advertising legislation and organizational support of state regulation of advertising activity in Ukraine. Moreover, the forecast of perspective volumes of advertising market of eco-friendly products in developing countries on the example of Ukraine within the next three years showed that the share of advertising market of eco-friendly products in Ukraine on a global level would make only $0.2 \%$ in 2019 .

The actions allowing stimulating advertising activity in developing countries with the prospect of increase of its share within the world advertising market of eco-friendly products are offered. These actions are mainly based on granting tax benefits to enterprises, which manufacture promotional products and on state support of innovative advertising projects.

\section{References}

Bovee, C.L., Arens, W.F. (1989). Contemporary advertising, Homewood, Irwin.

Bovee, C.L., Thill, J.V. (1992). Marketing, New York, McGraw-Hill, 662.

Granger C.W.J. (1990). Modeling Economic Series, Oxford, Oxford University Press, 419.

Little J.D.C. (1996). A Model of Adaptive Control of Promotional Spending. Operations Research, 163, $175-197$.

Kropyvnytskyi, V.S., Maistro, S.V., Shvedun, V.O., Stankevych, S.V. (2020). Prognosis of emergencies and their impact on population and territory of Ukraine. Ukrainian Journal of Ecology, 10(4), 218-224.

Krukov, A.I., Radchenko, O.V., Radchenko, O.O., Garmash, B.K., Biletska, Ye.S., Ponomarenko, R.V., Sysoieva, S.I., Stankevych, S.V., Vynohradenko, S.O. (2020). Experience of developed countries in state environmental safety policy. Ukrainian Journal of Ecology, 10(2), 190-194.

Nelson, P. (1974) Advertising as Information. Journal of Political Economy, 82, 729-54.

Shvedun, V. O., Streltsov, V., Husarov, K. O., Sysoieva, S. I., Sheludko, R. M., Stankevych, S. V., Butenko, T. A., Tkachenko, T.G., Khmyrova, A.O. (2019). The Ukrainian market of ecological tourism: the current trends and development. Ukrainian Journal of Ecology, 9(4), 598-605.

The Internet advertizing share in global expenses will reach $40 \%$ in 2019 (2018). Available from: http://mmr.ua/tags/ZenithOptimedia\#1556036473.1518525932/

The world advertising market was stabilized (2014). Available from: http://www.advertology.ru/article117805.htm/

Ulyanchenko O.V., Borysova O.V., Akhmedova O.O., Sysoieva S.I., Sheludko R.M., Stankevych S.V., Kovalova T.V., Khalmuradov B.D., Kharlamova Yu.Ye. (2019). Prospective use of ecological tourism in Ukraine and integrative view of international experience. Ukrainian Journal of Ecology, 10(1), 49-54.

Volume of the advertising and communication market of Ukraine 2017 and forecast of volume of the market of 2018 (2018). Available from: http://sostav.ua/publication/obem-reklamno-kommunikatsionnogo-rynka-ukrainy-2017-i-prognoz-obemov-rynka2018-73391.html/

Wilson, J.H., Keating B. (1994). Business Forecasting, Irwin, McGraw-Hill Companies.

Zenith Optimedia: the global advertising market will grow by $6.1 \%$ in 2017 (2016). Available from: http://mmr.ua/show/zenithoptimedia-globalnyj-reklamnyj-rynok-vyrastit-na-61-v-2017-godu/39159\#1556036473.1518525932/

\section{Citation:}

Yevsuykov, O.P., Akhmedova, O.O., Sysoieva, S.I., Stankevych, S.V., Vasiliev, A.A., Anichkin, Ye.S. (2020). Global advertising market of eco-friendly products in developing countries: A review of the current trends and prospects. Ukrainian Journal of Ecology, 10(5), 136-141. 